\title{
Daily Living Activities of Children with Mild Mental Retardation: Effect of Nursing Intervention
}

\author{
Jehan Mahmoud Farrag, Wafaa El-Sayed Ouda, Amal Ahmed Khalil, Manal Farouk \\ Ebada \\ Assistant Lecturer of pediatric Nursing-Port Said University; Professor of Pediatric \\ Nursing- Ain Shams University; Professor of Pediatric Nursing- Port Said University; \\ Lecturer of Pediatric nursing-Suez Canal University
}

\begin{abstract}
Background: When a child with mental retardation is born, parents need assistance in promoting normal developmental skills that are almost automatically learned by other children. The aim of this study was to assess activities of daily living of mildly mentally retarded children, plan, implement and evaluate nursing intervention program based on their needs. The research design was a quasi experimental research design . The present study was carried out at El Tarbya El Fekrya governmental school serving mildly mentally retarded children in Port Said City. The sample of the present study was 34 children. The tool that was used for data collections was adopted from Waziry (2002). The observational checklist was used twice pre and post program intervention for assessing the children's degree of independency related to daily living activities. The results revealed that all daily living activity skills namely; eating, drinking, dressing, grooming, personal hygiene and toileting skills are improved post intervention programme comparing with pre intervention with statistical significant difference in all of them.Itwas concluded that implementation of the designed nursing intervention program was successful in improving mildly mentally retarded children's skills. The study recommended design a periodic training program for mildly mentally retarded children and their parents according to their actual needs in the area of daily living activities, to help them to grow and develop to their optimal capacities to be independent in their life.
\end{abstract}

Key Words: Effect, Nursing intervention, Mental retardation, Daily living activities, Children 


\section{INTRODUCTION}

When a cognitive impaired child (CI) is born, parents need assistance in promoting normal developmental skills that are almost automatically learned by other children. These include self care skills such as feeding, toileting, dressing and grooming. Teaching these skills requires a basic knowledge of the developmental sequence in learning the skills demonstrated by children of average intelligence (e. g., children with sub average intelligence would not be expected to dress themselves as early as normal youngsters) (Hockenberry,2011).

The mentally retarded children's problems aren't merely in the education and learning but it expand to the social field that consider essential element for their interaction with other surrounded. This interaction is reflected in the ability of those children in performing the activities of daily living and practicing needed activities in the community (Malky,2008).

The term intellectual disability is increasingly being used instead of mental retardation (Schalock \& Luckasson, 2007). In new references CI is used with intellectual disability and the outdated term mental retardation (Hockenberry, 2011).The definition of CI developed by the American Association on Intellectual and Developmental Disabilities (AAIDD) emphasizes the child's functional strengths and weakness and the environmental supports to the child's needs. The intensity of support required is classified as intermittent, limited, extensiveor pervasive. The underlying assumption is that when appropriate supports are given over a prolonged period, the ability of child with CI to function each day will generally improve for educational purpose (Johnson \& Walker, 2006).

\section{Significance of the Study:}

Cognitive impairment occur in $2.5 \%$ to $3 \%$ in general population. Out of which $85 \%$ are mildly cognitively impaired group, $10 \%$ are moderate who can effectively trained, producing a good results. Three to four percent are severely impaired and rests are profound cognitively impaired (Sharma, 2013, Husain, 2010 \& Lachaplle, 2008) .According to the world health organization (WHO), mild mental retardation in Egypt represent $2.5 \%$ which reveals that the expected numbers of school age children to have mild mental retardation almost 37.200 child in $1992 \& 43.500$ child in 1997 (Abd ElGhaffar, 2003).So, there was an important need to conduct this study to identify inappropriate activities of daily livings for those children, and develop a nursing intervention program for them. Thus, This study will contribute in improving skills of those children, as well as helping in living independent as possible. 


\section{AIM OF THE STUDY:}

To assess daily living activities of mildly mentally retarded children, plan, implement and evaluate nursing intervention program based on actual needs assessment of those children.

\section{Research Hypothesis:}

The nursing intervention program (NIP) will be improving activities of daily living of mildly mentally retarded children.

\section{SUBJECTS AND METHODS:}

\section{Technical design:}

Research Design: A quasi experimental research design.

Setting: The study was conducted in Port Said City at El-Tarbya El-Fekrya School. It was the only available governmental school serving children with mild mental retardation.

Subjects: All children from the previous mentioned setting who were 34 child were enrolled they had the following criteria: Both genders, child's intellectual quotient (IQ) ranged from 50-75 (mildly retarded group), child's chronologic age ranged from 8-12 years, didn't enrolled inany similar educational program and free from any other health problems.

\section{Tool for data collection:-}

Observational checklist: was adopted from Waziry (2002). who quoted it from Litton (1978). It was applied by the researcher after making some modifications. It has been used twice pre and immediately post program intervention to assess the level of the studied children in performing activities of daily living (ADLs) and the degree of their dependency (dependent, partially dependent or independent). It had the following items:

1- Skills of eating and drinking

2 - Skills of dressing

- Wearing and taking off shirt.

- Wearing and taking off trousers.

- Wearing and taking off socks.

- Wearing and taking off shoes.

3- Skills of grooming and personal hygiene

- Combing hair.

- Hair clipping (for girls only)

- Cutting nails

- Hand washing

- Nose cleaning ( by tissue and water)

- Face washing.

- Mouth washing.

- $\quad$ Teeth brushing. 


\section{4- Toileting skill}

\section{Scoring system:}

To determine the degree of dependency of studied children in ADLs the following scoring was done: for each skill question a score $=0$ if dependent, 1=partially independent and 2 if done completely independent. Then the score of the aspects of the skill were added and a percent was calculated, e.g., Eating skill included 20 questions with a maximum score of 40 , if a child scored 10 this was transformed into $25 \%(=10 / 40)$. This will help to identify the best and worst skill. The before-after comparison was done by comparing the $\%$ score before and after.

\section{Operational design:}

The operational design involved description of preparatory phase, pilot study and field work.

\section{Preparatory phase:}

During this phase, the researcher reviewed the literature in order to get acquainted with the research problem and to develop the data collection tools. It involved computer search of database and scientific resources at the local as well as the international levels

\section{Pilot study:}

A pilot study was carried out including $10 \%$ (4 children) of the sample size of children who were having mild mental retardation. The purpose of this study was to test the clarity, feasibility and consistency of the tools. Based on the findings of the pilot study, the necessary modifications were made in the tool, for example, all questions that measured knowledge of children were omitted as: what is the importance of hand washing?. This simple question was considered very difficult for those children. The final form of the study tool was prepared and the time needed for completing the checklist was determined. The tool had 15 skills, each child needed around complete school day from 8 a.m. to 12.30 p.m to complete the observational checklists of ADLs (around 4 hours). Pilot subjects were excluded from the main study sample but later they had the entire nursing intervention program (NIP).

\section{Field work:}

The study was conducted through the following steps:

A questionnaire sheet that had biosocial data of the studied children was used pre NIP application. The ADLs of the studied children were assessed pre / post NIP application using observation checklist. Every child was observed in the presence of the mother or social worker or even the school worker. To avoid embarrassment and to gain the child's cooperation. The researcher was available daily, 5 days / week from 7.30 a.m. to 1 p.m along the study period during a regular school day. Educational program was constructed based on actual needs assessment of the studied children Nursing intervention program was applied basically in the social club at the school, but when 
it wasn't available, training was done in the theater of the school in addition to the bathroom to complete the training.

During application of the program; the researcher was dealing with one child only or maximum two in each session. Different teaching strategies were used in training of children such as; role play, demonstration, re-demonstration, discussion and almost real equipment. Implementation of the NIP according to physical, mental readiness and the level of understanding for both mothers and studied children. Intervention was carried out through step by step demonstration using task analysis technique; each task was separated into its necessary components and each step is taught before proceeding to the next activity. Frequent repetitions of steps especially difficult one were done

The researcher provided the studied children with all equipments needed for the completion of the activities. The researcher was eager to keep children happy, avoid their boredom through continuous psychological motivation (praise, clapping and encouragement), physical motivation (cola, juices, chips, chocolate, gum, biscuits and everything children asked for) on a daily basis. At the end of the study every child took all the equipment that he was trained by, aiming at keeping good relationship and cooperation between the researcher and the children. The instructional scheme was conducted in 12 training sessions, each session included (1 -2) skills for individual child or 2 children only. The time of each session ranged from $30-120$ minutes according to difficulty of the skills and children's responds and readiness every child had chances for repetition of the skills at any time especially that their teachers were friendly with me.

Social workers helped the researcher to bring mothers by sending letters to them (with children) or through telephone conversation, with a financial incentive from the researcher at each time they come, in the form of money and offering transportation fees. Mothers actually did not mind for attendance. Evaluation of the studied children was carried out immediately after NIP implementation to assess the improvement compared with pre NIP assessment in ADLs of children. Total time was consumed for completion of data collection was around 12 months, including time of the vacation, from the beginning of October 2011 to the end of September 2012. A comparison was done to identify the effect of the implemented NIP on children's practices regarding their ADLs, pre and immediately post the NIP application.

\section{Limitations of the study:}

Difficulty to collect data related to the political situations experienced by the country, which led to the absence of the studied children and school closures in several times.

\section{Administrative design:}

1. Administrative approval to carry out the study through an issued letter from dean of the faculty to administrator of the study setting including:

a. Undersecretary of the Ministry of Education. 
b. Director of special education schools.

c. Director of El Tarbya El Fekrya school in the same.

2. Personal communication with school director, teachers, psychologists, social workers and the employees were carried out to ensure their cooperation in the school.

3. Two letters were sent to parents of the studied children; the first for taking their consent to work with them and the second letters to ask parents to mention sweets, drinks and food which are loved by their children. The researcher can use it as a motivation of the studied children during application of the study. Letters were written by the researcher and were sent by children by psychologists or social workers in the school.

\section{Statistical design}

Data entry and statistical analysis were done using SPSS 14.0 statistical software package. Data were presented using descriptive statistics in the form of frequencies and percentages for qualitative variables and means and standard deviations for quantitative variables. Statistical testing of the change in the abilities by marginal homogeneity test (Std. MH Statistic) was used. Quantitative continuous data were compared using student t- test in case of comparisons between two groups. Whenever the expected values in one or more of the cells in a $2 \times 2$ tables was less than 5 , Fisher exact test was used instead, in larger than $2 \times 2$ cross- tables. Statistical significance was considered at $\mathrm{p}$-value $<0.05$ and highly significance at $\mathrm{p}$ - value $<0.001$.

\section{RESULTS:}

As shown by table 1, figures 1 and 2; there were statistical significant improvement in all aspects of activities of daily living post compared with prenursing intervention program. $\mathrm{p}$ value $<0.001$. Where hair combing, nail cutting and brushing teeth skills showed the highest improvement with highest mean differences 48.2, 41.2 and 40.7 respectively, while drinking, wearing trousers and wearing shoes skills showed the least improvement with lowest means differences 15.6, 18.4 and 19.9 respectively. 
Table 1: Differences between total means scores of all activities of daily living pre/immediately post nursing intervention program.

\begin{tabular}{|c|c|c|c|c|c|c|c|c|}
\hline \multirow[t]{2}{*}{ Skills scores \% } & \multicolumn{2}{|c|}{ Pre } & \multicolumn{2}{|c|}{ Post } & \multicolumn{2}{|c|}{$\begin{array}{c}\text { Difference } \\
\text { between } \\
\text { means scores } \\
\text { post and pre } \\
\text { NIP }\end{array}$} & \multirow[t]{2}{*}{ t. test } & \multirow[t]{2}{*}{ P-value } \\
\hline & Mean & S.D & Mean & S.D & Mean & S.D & & \\
\hline Eating & 43.8 & 18.9 & 76.4 & 14.1 & 32.6 & 14.8 & 12.876 & $<0.001 * *$ \\
\hline Drinking & 75.0 & 23.0 & 90.6 & 13.7 & 15.6 & 15.0 & 6.054 & $<0.001 * *$ \\
\hline Wearing \& taking off shirt & 39.2 & 27.5 & 74.0 & 26.1 & 34.8 & 16.6 & 12.226 & $<0.001 * *$ \\
\hline $\begin{array}{l}\text { Wearing \& taking off } \\
\text { trousers }\end{array}$ & 69.5 & 33.5 & 87.9 & 18.8 & 18.4 & 19.6 & 5.457 & $<0.001 * *$ \\
\hline Wearing \& taking off socks & 60.1 & 26.3 & 87.2 & 18.2 & 27.1 & 16.8 & 9.432 & $<0.001 * *$ \\
\hline Wearing \& taking off shoes & 71.7 & 27.1 & 91.5 & 16.8 & 19.9 & 20.4 & 5.664 & $<0.001 * *$ \\
\hline Hair combing & 28.9 & 18.9 & 77.0 & 22.9 & 48.2 & 16.0 & 17.52 & $<0.001 * *$ \\
\hline Hair clipping & 29.8 & 29.6 & 69.2 & 34.5 & 39.4 & 27.4 & 5.186 & $<0.001 * *$ \\
\hline Nail cutting & 20.6 & 24.7 & 61.8 & 28.2 & 41.2 & 23.5 & 10.204 & $<0.001 * *$ \\
\hline Hand washing & 69.1 & 18.4 & 92.0 & 12.3 & 22.9 & 14.2 & 9.434 & $<0.001 * *$ \\
\hline Nose care with water (1) & 52.9 & 27.9 & 87.7 & 19.6 & 34.7 & 23.0 & 8.801 & $<0.001 * *$ \\
\hline Nose care with tissue (2) & 56.2 & 24.9 & 84.4 & 17.1 & 28.2 & 21.4 & 7.698 & $<0.001 * *$ \\
\hline Face washing & 61.0 & 19.7 & 85.9 & 18.3 & 24.8 & 15.1 & 9.574 & $<0.001 * *$ \\
\hline Mouth washing & 62.9 & 24.6 & 89.5 & 17.7 & 26.6 & 19.1 & 8.115 & $<0.001 * *$ \\
\hline Teeth brushing & 32.5 & 20.9 & 73.2 & 23.5 & 40.7 & 18.4 & 12.868 & $<0.001 * *$ \\
\hline Toilet care & 51.7 & 17.9 & 77.7 & 17.2 & 26.1 & 12.5 & 12.136 & $<0.001 * *$ \\
\hline Total score & 50.3 & 17.3 & 80.0 & 14.6 & 29.7 & 9.9 & 17.516 & $<0.001 * *$ \\
\hline
\end{tabular}

(*) Statistically significant difference at $p<0.05$ significant difference at $p<0.001$

(**) high statistical 


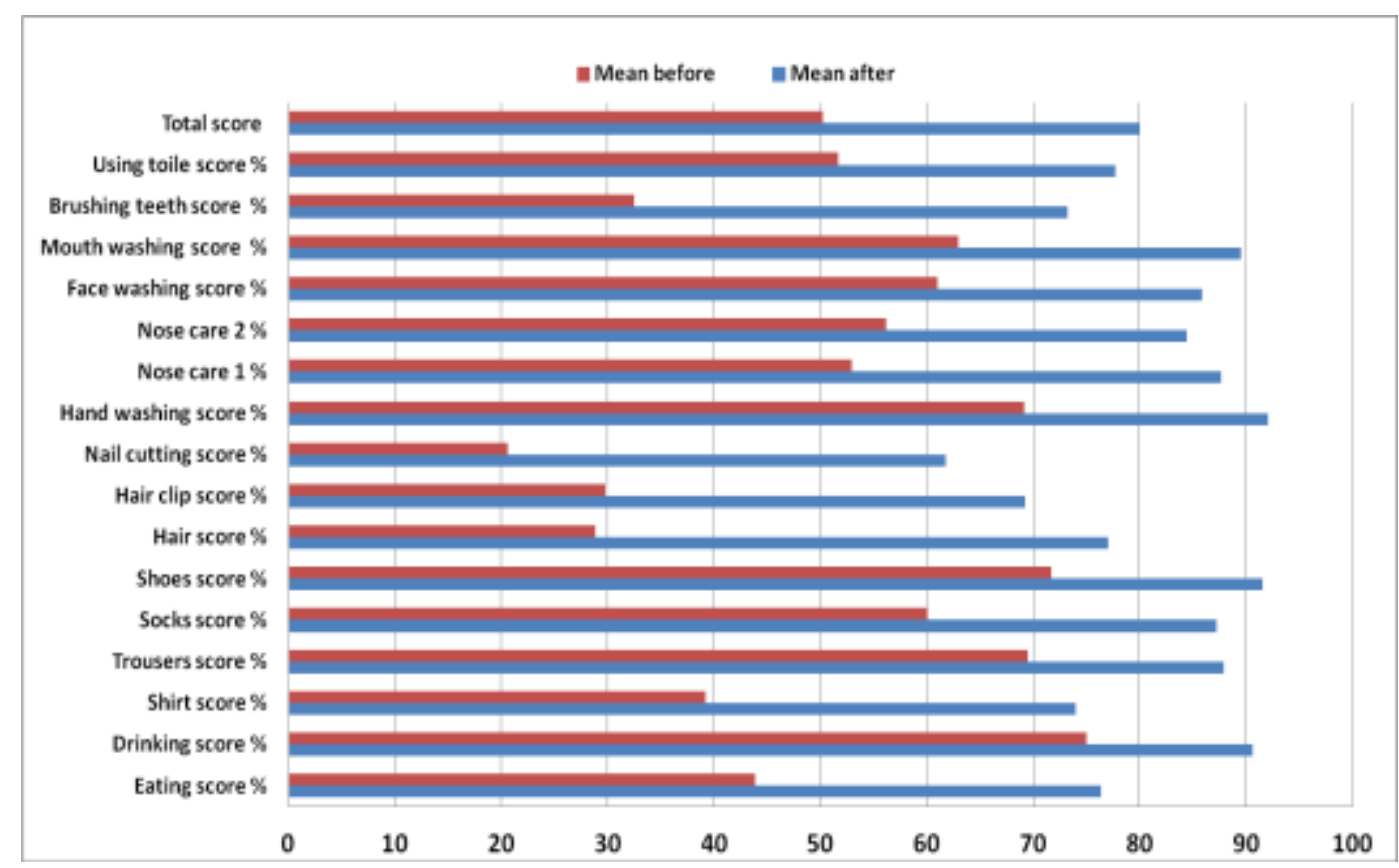

Figure 1: Total means scores of all skills pre / post nursing intervention program

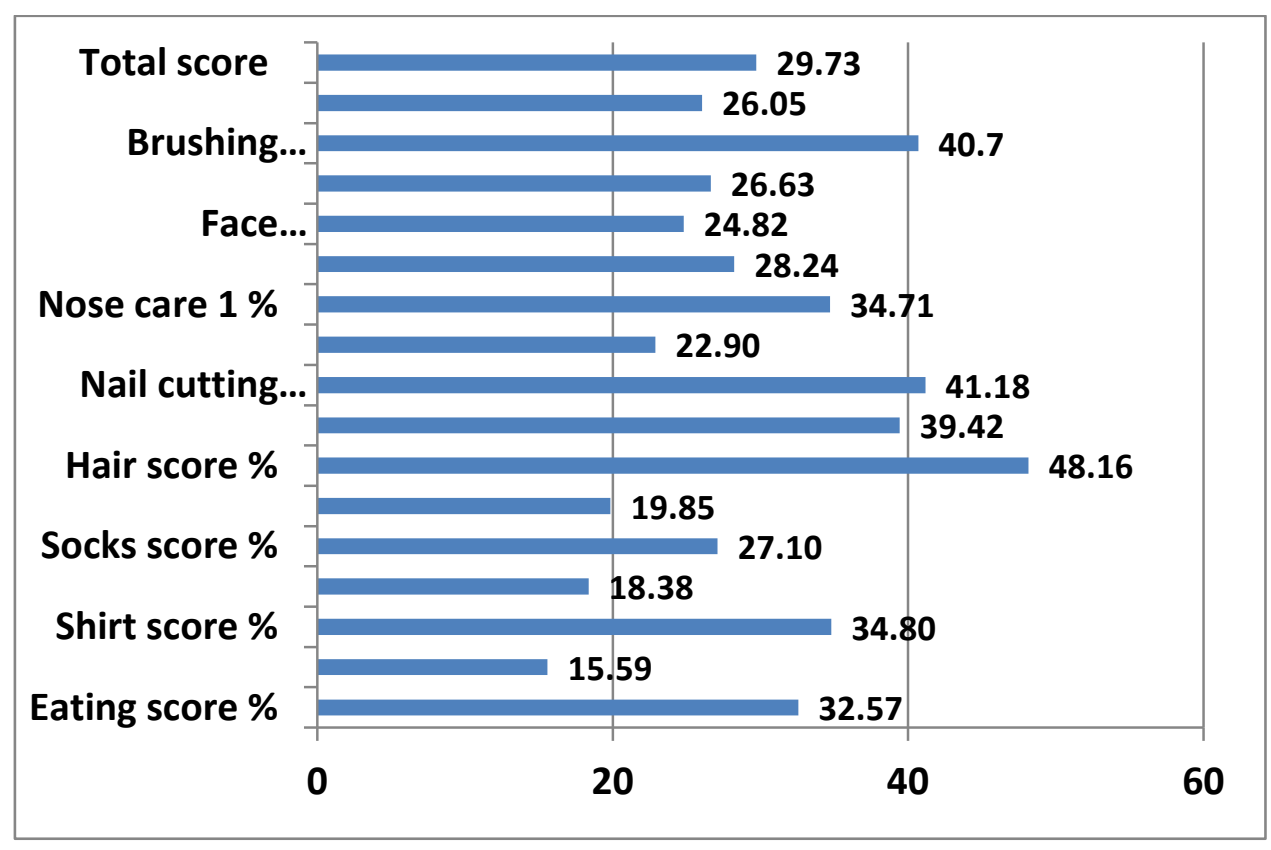

Figure 2: Differences between total means scores of all skills pre/ post nursing intervention program

As shown by table 1, figures 1 and 2; there were statistical significant improvement in all aspects of activities of daily living post compared with prenursing intervention program. p value $<0.001$. Where hair combing, nail cutting and brushing teeth skills showed the highest improvement with highest mean differences 48.2, 41.2 and 40.7 respectively, while drinking, wearing trousers and wearing shoes skills showed the least improvement with lowest means differences 15.6, 18.4 and 19.9 respectively. 


\section{DISCUSSION:}

Children can improve their functional independence by undergoing vocational training in independent living skill. In the present study, it was clear that eating skills of the studied children improved significantly post nursing intervention program (NIP), These results are consistent with (El Mahdy, 2002) study entitled (Daily living activities of educable mentally retarded children: Effect of an educational program)\& (Wong, 2000), who mentioned that mildly mentally retarded child can acquire practical skills as feeding skills. Poor performance of the studied children before application of the program may be related to mothers lack confidence in their children abilities to give them a chance to be independent.

The studied children had improved significantly post NIP' compared with pre program in drinking skills. This finding could be due to that drinking skills was easy to be learned, children already practice it constantly at home pre NIP but not perfectly as in the post NIP. This result was in an agreement with (Blinder, 1995) who mentioned that, children with mild mental retardation can be taught activities of daily living through guidance about the care needed in drinking, dressing, feeding, toileting and hygiene.

Regarding wearing and taking off shirt skills, it had been improved with highly SSD post NIP compared with pre program finding, where the majority of the studied children were dependent and improved to be independent, the most difficult step that faced the researcher was buttoning the shirt but the researcher overcomes this problem by daily repetition of it with other skills training. This supported by (Scipine et al., 1990), who reported that, many of mentally retarded children are very clumsy in both fine and gross motor ability. They have spatial disorientation i.e. they cannot discriminate between rights and left, up and down, under and over, around and through, etc, in addition, most of those children are hyperactive, disorganized, and restless and have short attention span.

It was observed that, there were improvement in wearing and taking off trousers skills with SSD pre and post the NIP. This finding is supported by (Wong, 2000), who mentioned that, level of independence in dressing varies according to degree of mental retardation. Children with mild mental retardation who don't have physical limitations can become independent in all dressing skills by special training except for more complex tasks.

In relation to wearing and taking off socks skills; there were obvious improvements in performing this skills post NIP comparing with pre program. These results are consistent with the results of (Waziry, 2002) study entitled, who found that a greatest improvement was observed in the skills of putting on and taking off socks after application of the program. The problem that faced the researcher during preparatory stage; was wearing socks with heels, the children were not able to rotate the bottom of the heel and the other part to the top. The researcher had overcome this problem by replacing socks with another one that did not have heels. 
Regarding wearing and taking off shoes, there were improving in these skills in both steps of putting on and taking shoes off. Knowing that all the shoes were almost taped and did not have ligaments, this is recommended for those children and making it easier for researcher in training process.(Varcarol, 1990) also mentioned that children with mild mental retardation can accomplish even the most simple skill and that which may be very difficult. Learning to tie shoes may take same or more effort as normal child.

Concerning hair combing, hair clipping skills there were extremely improvement from dependency to independency state post NIP. This result is compatible with (Waziry, 2002) who found that the majority of children were poor before program and become good immediately post NIP. It is worth mentioning that, there were some simple tools that were used in training on this activities and had a great effect in motivating the studied children and increasing their desire for training; such as hair creams, hair combs with different colors, use the mirror, and attractive colors of hair ornament ( for girls ). This make it easier for the researcher mission, taking into account that the majority of the studied girls had short hair, which may be related to fear of mothers from the emergence of hair insects in their daughters' heads, which also contributed to facilitate the task of the researcher.

Regarding nails cutting skills pre / post NIP, the majority of children were dependent in most of the steps of the above mentioned skill pre program. This finding is supported by (Bobby, 2013) study who found that, out of 60 children who are mentally retarded, 85\% cannot clips and clean their nail independently. The most difficult step that faced the researcher was pressing nail clipper and cutting nails because most of mentally retarded children that the researcher deals with them can not accurately control their fingertips. The researcher overcome this problem by making children try out many times on the plastic scraps, before they try on themselves during application of the NIP.

In relation to hygienic care skills which are: hand washing, face washing, mouth washing and nose care ( by either blowing in water or blowing in tissue); the majority of the studied children improved post the program application. This improvement could be due to those skills are performed on a daily base and may be repeated more than one time daily. This gave the studied children a chance to be efficient in performing these skills through its daily repetition.( Pillitteri, 1995) reported that, repetition of actions for mentally retarded children plays an important role in teaching such skills. Compared with other skills; such as brushing teeth skill which are considered as an extremely complex skill faced the researcher in children's training. This is could be due to lake of maternal practice /guidance of their children to brush their teeth, in addition to poor fine and motor skills of the children to be able to hold the tooth brush and control of its using correctly.

Regarding toileting skills; the present study clarified that, this skill is improved with high statistical significance difference after application of NIP compared with pre 
application. The result is consistent with (Waziry, 2002) who said that: assistance was provided only in some difficulties associated tasks as turning on the flush with a reasonable speed, then they reached to considerable degree of independent in toileting skills after training program and (Schult et al., 2001)who mentioned that children with mild mental retardation can be taught to perform certain acts successfully, such as elimination control / toilet training.

\section{CONCLUSION:}

Based on the findings of the present study, it can be concluded that :There were significant improvement in all aspects of activities of daily livings with statistically significance difference; evaluated after the application of nursing intervention program.

\section{RECOMMENDATIONS:}

Designing similar periodic training programs as a part of management plan for mildly mentally retarded children and their parents according to their actual needs in area of daily living activities to help them to grow and develop to their optimal capacities to be independent in their life.

\section{REFERENCES:}

Abd El-Ghaffar, A., R. (2003): Educational care for people with special needs, Department of educational and psychological sciences, Faculty of specific education, Ain Shams University, Dar Al -Fagr for publication and distribution. Deposit No. 15254.

Blinder, J. (1995): Pediatric nursing care for children, $1^{\text {st }}$ ed. Appleton and Lange, USA. P.p. 336- 337

Bobby, K., K. (2013): Parental care and maintenance of personal hygiene of mentally challenged children with special reference to Calicut District, Doctorate thesis, Department of Social Work, Pondicherry university, India

El Mahdy, N. H. F. (2002): Daily living activities of educable mentally retarded children: Effect of an educational program, Unpublished Doctorate Thesis, Pediatric Nursing, Faculty of Nursing, Ain Shams University, P.P.40-49.

Hazlett, H., C. (2005): Down syndrome. In S. Goldstein \& C. R. Reynolds (Eds.), Handbook of neuro-developmental and genetic disorder in adults, N Y: Guilford Press. New York, P. p. 350-366.

Hockenberry, M., J. and Wilson, D. (2011):Wong's nursing care of infants and children, $9^{\text {th }}$ ed., Elsevier, Mosby, Canada, P.p. 908-922. 
Husain, A. (2010): Behavioral problems and social maturity among mentally challenged and autistic children, Disabilities and Impairment, 26 (4): 101- 107.

Johnson, C., P. and Walker, W., O. (2006): Mental retardation management and prognosis, Pediatric Rev., 27 (7): 249 -256.

Lachaplle, Y., (2008): The intellectual disability construct and its relation to human functioning. Intellect. Dev. Disabil., 46(4): 311-8

Litton, $\boldsymbol{F}$., $\boldsymbol{W}$. (1978): Education of trainable mentally retarded. Saint Louis: Mosby Company, P.p. 95- 115.

Malky, H., A. (2008): Adaptive skills of special program and institution students in Riyadh city, Published Master Thesis, special education, Faculty of Education, The Saud King University, P. 39.

Pillitteri, A. (1995): Maternal and child health nursing: Care of the child bearing and rearing family, $2^{\text {nd }}$ ed., Philadelphia: J. B, Lippincott company, P.p 1719- 1728.

Sharma, p. (2013): Essential of mental health nursing, $1^{\text {st }}$ ed., Rajkamal Electric Press, India, P.p. 268- 275.

Schalock, R., L. and Luckasson, R., A. (2007): The renaming of mental retardation: Understanding the change to the term intellectual disability, Intellect. Dev. Disabil., 45(2):116-24.

Schult, E., Price, D. and Gwin, J. (2001): Pediatric nursing, An introductory text, $8^{\text {th }}$ ed., W. B. Saunders company, Philadelphia, p.p. 240

Scipine, C., Chard, M. and Houe, J. (1990): Mental retardation in pediatric nursing care, $3^{\text {rd }}$ ed., Philadelphia: Lippincott company, P. p. 20-27

Varcarol, S. (1990): Foundation of psychiatric mental health nursing, $4^{\text {th }}$ ed., W. B. Saunders company, Philadelphia, P.p. 240- 250.

Waziry, $\boldsymbol{O}$. (2002): The effect educational program on improving self care of mentally retarded children, Doctorate Thesis, Pediatric Nursing, Faculty of Nursing, Alexandria University.

Wong, L. (2000): Chronic illness, disability and death, $2^{\text {nd }}$ ed., Mosby, Texas, P. p.1000- 1033 


\section{تأثير تلخل تمريضي على أنثطة الحياة اليومية للأطفال المتأخرين عقلياً بدرجة بسيطة}

جيهان محمود فراج ، أ. د. وفاء السيد عبد الجليل ، أ.د. امل احمد خليل ، د. منال فاروق عبادة

مدرس مساعد تمريض الاطفال - جامعة بورسعبد ،/ستاذ تمريض الاطفال - جامعة عين شمس ،/ستاذ تمريض الأطفال- جامعة بورسعيد،مدرس تمريض الاطفال - جامعة قناة السويس

\section{الخلاصة}

عند و لادة طفل يعاني من انخفاض في المستوى العقلي، قد يكون الآباءو الأمهات بحاجة إلى المساعدة في تعزيز المهار ات التنموية الطبيعية لهذا الطفل و التي ينم اكتسابها تلقائيا من قبل الأطفال الطبيعيين. لذا فقد كان الهدف من هذه الدراسة هو تقييم مدى قدرة الأطفال المتأخرين عقليا بدرجة بسيطة على القيام بأنشطة الحياة اليومية. أيضا تخطبط وتنفيذ وتقييم مدى تأثثير برنامج تدخل تمريضي على أنثطة الحياة اليومية لهؤلاء الأطفال بناءا على نتيجة تقييم احتباجاتهم الفعلية. و لقد نم إجراء هذه الدراسة على 34 طفلاً في مدرسة التربية الفكرية الحكومية في محافظة بورسعيد التي تخدم هؤلاء الأطفال.تم استخدام استمارة الملاحظة مرتين: قبل و بعد لهده تطبيقالبرنامج مبانشرة لتقييم درجة الاستقلالية المتعلقة بأنشطة الحياة اليومية لهؤلاء الأطفال. أفادت نتائج الدراسة

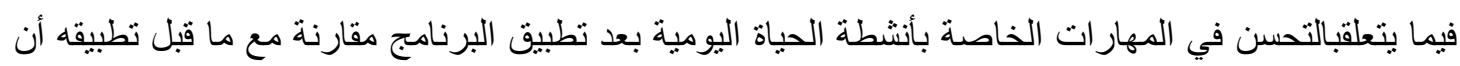

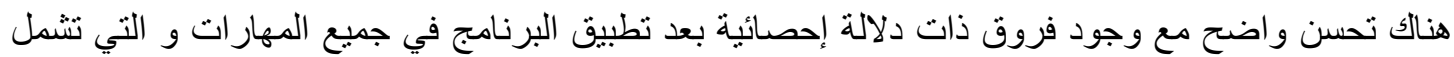
مهار ات الأكل و الثرب، مهار ات خلع الملابس و ارتداءها، مهار ات الاهتمام بحسن المظهر و النظافة الثخصية

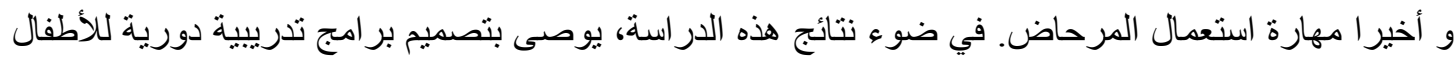
المتأخرين عقليا بدرجة بسيطة و لأولياء أمورهم وفقا لاحتياجاتهم الفعلية في مجال أنثطة الحياة اليومية، لمساعدتهم في نمو وتطوير قدر اتهم لتصل إلى احسن درجة من الاستقلالية في ممارسةانشطة حياتهم اليومية. 